\title{
Forgrunding af ledsætninger - et psykolingvistisk forsøg
}

\section{Marie Herget Christensen, Tanya Karoli Christensen \& Torben Juel Jensen}

\begin{abstract}
It is a common phenomenon in spoken language that the main point of an utterance is found in a syntactically subordinated clause instead of in its matrix clause. This is the case in constructions where the matrix clause is semantically secondary as well as in subclauses with $\mathrm{V}>\mathrm{Adv}$ word order in Danish. We argue that such subclauses are foregrounded, and that a foregrounded subclause will attract more attention than a non-foregrounded. To test this, we have conducted an experiment under the Text Change paradigm. Results show that readers pay significantly more attention to the subclause in constructions with semantically secondary matrix clauses than in constructions with semifactive matrix clauses, and, in the latter constructions, more attention to subclauses with $\mathrm{V}>\mathrm{Adv}$ word order than with $\mathrm{Adv}>\mathrm{V}$ word order.
\end{abstract}

Nøgleord: sætningsprocessering, ledsætninger, forgrund, ledstilling, ændringsblindhed

\section{Indledning}

I helsætninger bestående af en matrixsætning og (mindst) en ledsætning vil den vigtigste information i mange tilfælde skulle findes i ledsætningen på trods af at den syntaktisk set er underordnet. Det gælder ikke mindst i konstruktioner med indholdslette, dvs. epistemisk eller tekstuelt modificerende, matrixsætninger som det er sådan og jeg tror i (1) og (2):

(1) Det er sådan at hun tør godt klatre helt derop

(2) Jeg tror hun kommer i morgen 
En af de problemstillinger der har været rejst i den internationale litteratur om forholdet mellem indholdslette matrixsætninger som i (1) og (2) og deres ledsætninger, er hvorvidt der overhovedet er tale om den syntaktisk-hierarkiske relation matrixsætning-ledsætning. Thompson og Mulac (Thompson \& Mulac 1991a; Thompson \& Mulac 1991b) argumenterer således for at i hvert fald epistemiske konstruktioner som I think eller på dansk jeg tror fungerer parentetisk (Urmson 1963) eller som adverbiallignende modificeringer af det egentlige sætningsindhold, nemlig det som findes i "ledsætningen" - som i så fald egentlig ikke udgør en ledsætning, men en helsætning i sig selv. Boye og Harder (2007) diskuterer indgående Sandra Thompsons senere analyse af de "formulariske fragmenter" (dvs. de parentetiske sætninger) (Thompson 2002) - og pointerer - som også understreget i Grammatik over det Danske Sprog (GDS; Hansen \& Heltoft 2011) - at de ikke generelt kan antages at optræde med parentetisk funktion, og dermed være baggrundsinformation. Der vil være tilfælde hvor en epistemisk matrixsætning udtrykker det vigtigste indhold i sætningskomplekset, som når man understreger at man tror, snarere end ved, at noget er tilfældet. Det er således ikke givet hvor den vigtigste information i helsætningen findes, eller med andre ord om matrixsætningen eller ledsætningen er i forgrunden semantisk set, dvs. forgrundet.

På dansk er den parentetiske funktion tydeligt kodet i de typisk finalt placerede konstruktioner med den faste ledfølge finit verbal-subjekt (tror jeg). I disse tilfælde er det altid "ledsætningen" som er forgrundet. Modsat er initialt placerede subjekt-verbal-konstruktioner principielt tvetydige: De kan enten have funktion som en reel matrixsætning med valenskrav fra hovedverbet til ledsætningen eller parentetisk funktion uden sådanne valenskrav (sammenlign *Hun hostede at det kunne ikke passe og Det kunne ikke passe, hostede hun (jf. Hansen \& Heltoft 2011; Christensen 2007). I disse tilfælde vil der være en række andre sproglige faktorer der kan entydiggøre hvilken del af sætningen som er forgrundet: I talesprog vil prosodien formentlig være ganske afgørende, men sammenhængen mellem prosodi og forgrunding er ikke velbeskrevet nok til at den kan operationaliseres i en videnskabelig undersøgelse. Derudover findes der andre velbeskrevne midler til at fokusere eller forgrunde en del af sætningskomplekset, fx kløvningskonstruktioner og fokusoperatorer; men som vi vil argumentere for i denne artikel, kan ledsætningens ledstilling også have denne funktion.

Det er velbeskrevet $\mathrm{i}$ dansk at ledstilling koder flere slags betydning, $\mathrm{fx}$ forskellen på fremsættende og spørgende sætninger, såkaldt illokutionør ramme og syntaktisk ledfunktion (jf. rækkefølgen indirekte > direkte objekt). Som det 
fremgår af den valgte terminologi i GDS, indebærer valget mellem deklarativ og neutral ledstilling også en betydningsforskel. Forskellen er enklest at beskrive på ledsætningsniveau: Ledsætninger der følger det deklarative mønster (Verbal $>$ Subjekt $>$ Adverbial), har en mere specifik betydning end ledsætninger efter det neutrale mønster. I GDS kaldes denne betydning assertiv eller konstativ (Hansen \& Heltoft 2011: 1677 ff.), og det er en pointe at den er i modstrid med en læsning som præsupponeret. Sammenhold (1) ovenfor, som uproblematisk optræder med deklarativ ledstilling, med (3) herunder, som har et faktivt (her: evaluerende) prædikat i matrixsætningen hvilket medfører at ledsætningen bliver præsupponeret.

(3) Det er sejt at hun godt tør klatre helt derop (neutral) *at hun tør godt klatre helt derop (deklarativ - i modstrid med faktivt prædikat)

Den begrænsning findes ikke for ledsætninger med neutral ledstilling (Subjekt $>$ Adverbial $>$ Verbal). Som betegnelsen angiver, er denne ledstilling semantisk umarkeret og kan bruges i alle typer ledsætninger.

Vi har i andre publikationer argumenteret for at ledsætninger med deklarativ ledstilling bør læses som forgrundede, snarere end assertive (Jensen \& Christensen 2013; Christensen \& Jensen 2014; Christensen, Jensen \& Christensen 2015). Det skyldes bl.a. at denne ledstilling også forekommer i ledsætninger med konjunktionen om som strider imod assertiv betydning; jf. (4).

(4) det var noget med om psykologen kunne ligesom bringe os ud af fatning

En af de faktorer som i dansk talesprog korrelerer klart med ledstillingen i ledsætninger, er typen af matrixsætning. I vores tidligere korpusundersøgelser af nominale ledsætninger har vi skelnet mellem disse fire hovedtyper af matrixsætninger som de kan forekomme med (Jensen 2011; Jensen \& Christensen 2013):

(1) kodet parentetiske matrixsætninger (af tror jeg-typen)

(2) citerende matrixsætninger (hvor der er tempus- eller pronominalskift mellem matrixsætning og ledsætning, fx du sagde jeg er så tret af det)

(3) semantisk sekundære matrixsætninger, dvs. konstruktionelt baggrundede, indholdslette matrixsætninger som i eksempel (1), (2) og (4) ovenfor eller initialt placerede jeg tror 
(4) øvrige matrixsætninger (alle de matrixsætninger der ikke kan placeres i en af de øvrige grupper)

Fordelingen af deklarativ og neutral ledstilling i ledsætninger til de fire typer matrixsætning fremgår af Figur 1.

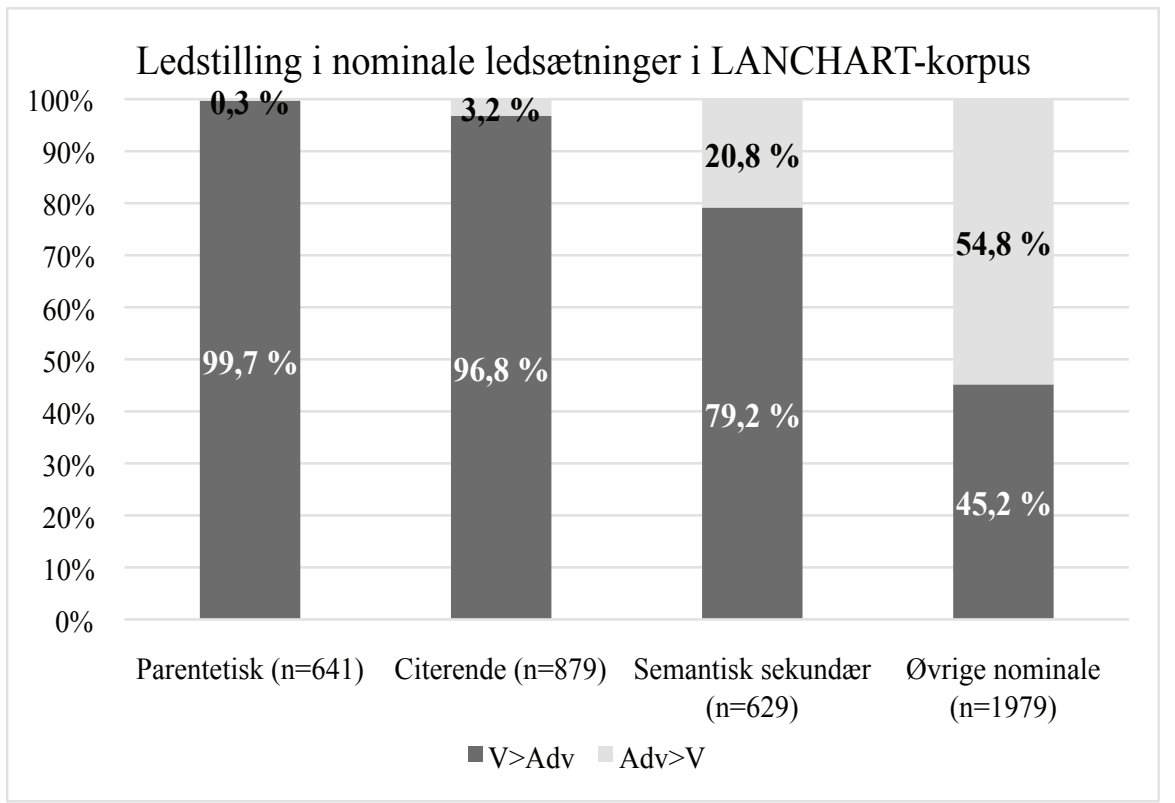

Figur 1. Fordelingen af deklarativ $(V>A d v)$ og neutral $(A d v>V)$ ledstilling inominale ledsetninger over fire typer matrixsetninger.

Som ventet forekommer kodet parentetiske og citerende matrixsætninger kun yderst sjældent med ledsætninger med neutral ledstilling (hhv. 0,3\% og 3,2\% af tilfældene). Ved de semantisk sekundære er der stadig en stor overvægt af deklarativ ledstilling, men dog en del variation (20,8 \% af ledsætningerne til disse matrixsætninger har således neutral ledstilling). Den store, ret blandede kategori af "øvrige" matrixsætninger har deklarativ ledstilling i 45,2 \% af ledsætningerne.

Inden for den sidste gruppe er der relativt store forskelle på fordelingen af ledstillingsmønstrene under forskellige "prædikatstyper. Som man ville vente, forekommer faktive prædikater (af typen "ærgre sig over", "være sjovt", jf. Karttunen 1971 og Hooper \& Thompson 1973) kun sjældent med deklarativ ledstilling, mens semifaktive prædikater udviser stor variation, omend med en lille overvægt til deklarativ ledstilling (60\%). Semifaktive prædikater er 
en kategori af prædikater som hovedsageligt beskriver den kognitive proces hvorved en person får en viden som hun ikke havde i forvejen, fx forstå, indse, blive klar over. De kaldes semifaktive fordi de ikke altid fremkalder en præsupponeret ledsætning, fx ikke når de er modaliseret af et modalverbum eller en betingelsessætning (Karttunen 1971). Faktisk viser Simons (2007) at selv umodaliserede semifaktiver kan være tvetydige mellem en faktiv og nonfaktiv tolkning, og at det kræver kontekst for at afgøre om ledsætningen eller matrixsætningen er forgrundet ('main point of the utterance'). Vi kan illustrere pointen med let reviderede eksempler fra Simons (2007: 1036):
a. A: Who was Louise with last night?
B: Henry found out that she was with Bill.
b. A: What is bothering Henry?
B: He found out that Louise was with Bill last night.

I (5a) er den vigtigste information i ledsætningen mens den i (5b) findes i matrixsætningen (i en sammenhæng hvor man antager at både $\mathrm{A}$ og $\mathrm{B}$ allerede ved hvor Louise har været). Selvom traditionen ville beskrive en matrixsætning som i (5a) som et godt eksempel på en præsuppositionsudløsende semifaktiv, kan den altså have en forgrundet ledsætning i kraft af den kontekst den indgår i. Ifølge vores undersøgelser sker det oftere end det omvendte: Når 60 \% af ledsætningerne under semifaktive prædikater forekommer med deklarativ ledstilling, er det ifølge vores analyse et tegn på at disse ledsætninger er forgrundede (Jensen \& Christensen 2013).

De undersøgelser vi hidtil har lavet, omhandler alle talesproglige produktionsdata og beskriver dermed mønstre i sprogbrugen. Men da vores antagelser om ledstillingens betydning i vidt omfang drejer sig om hvad man kan forvente at folk lægger mest mærke til i en ytring, er det relevant at udvide perspektivet til også at omfatte processeringsdata: Afspejler de grammatiskdiskursive signaler om forgrund sig i hvor opmærksomme sprogbrugere er på de forgrundede dele af ytringen, og hvor grundigt de processerer den? Resten af denne artikel afrapporterer et studie med netop dette fokus, hvor vi gør brug af en psykolingvistisk testtype som kaldes text change-metoden. Vi indleder med den hypotese som metoden skal teste. Den fokuserer på to udvalgte typer matrixsætninger, nemlig de semantisk sekundære, som man vil vente har forgrundede ledsætninger, og de semifaktive, som kan have enten forgrundede eller baggrundede ledsætninger, til dels signaleret ved ledsætningens ledstilling. 


\subsection{Hypotese}

Ledsætninger hvis matrixsætning udgøres af epistemiske eller tekstuelle ordforbindelser (eng.: phrases), er oftest forgrundede. Dette vil medføre at sprogbrugere er mere opmærksomme på ledsætningerne i disse konstruktioner end i konstruktioner hvor ledsætningen ikke er forgrundet.

I konstruktioner med semifaktive matrixsætninger (dvs. konstruktioner med ledsætninger som i udgangspunktet er åbne for såvel en forgrunds- som en baggrundslæsning) vil sprogbrugere have en større tendens til at være opmærksomme på ledsætningen hvis den har deklarativ ledstilling $(\mathrm{V}>\mathrm{Adv})$, end hvis den har neutral ledstilling $(\mathrm{Adv}>\mathrm{V})$.

Derimod vil ledstilling ikke spille nogen nævneværdig rolle som forgrundssignal for ledsætninger som allerede utvetydigt er forgrundede. Derfor forventer vi ikke nogen opmærksomhedsforskel relateret til ledstilling i ledsætningen hvis matrixsætning udgøres af en epistemisk eller tekstuel ordforbindelse.

\subsection{Text change-metoden}

Vi følger en forskningsretning inden for studiet af sætningsprocessering der antager at sprogbrugere økonomiserer med deres resurser og kun processerer nok til at opnå repræsentationer der er gode nok ('good enough') til formålet (Ferreira, Bailey \& Ferraro 2002). Hvad der er godt nok, afhænger af hvor vigtig informationen vurderes at være for sprogbrugeren, og denne vurdering styres af sprogbrugerens opmærksomhed på forskellige dele af sætningen (Sturt m.fl. 2004). I sætningsprocessering kan man teste denne opmærksomhed ved hjælp af text change-metoden, der har vist sig at være sensitiv over for forskellige typer af informationsstrukturelle fremhævninger, bl.a. kløvning og kontekstuelt markeret fokus (Sturt m.fl. 2004), kursivering og tryk (Sanford m.fl. 2006) samt ords grammatiske status (Christensen 2015a, 2015b).

Metoden bygger videre på en metode der tester visuel opmærksomhed, og som udnytter det psykologiske fænomen der kaldes ændringsblindhed (Sturt m.fl. 2004). Ændringsblindhed betegner det fænomen at vi er utilbøjelige til at opdage ændringer i allerede processeret information. Vores opmærksomhed er per default på forgrunden (af fx et fotografi), antages det, og vi er mindre opmærksomme på ændringer af noget der forekommer i baggrunden. Derfor vil en fremhævelse af information medføre en reduktion af ændringsblindheden. Sturt m.fl. (2004) har videreudviklet metoden til at teste ændringsblindhed i skriftsprog. I forsøg af denne type skal deltagerne først læse korte tekststykker og derefter genlæse samme tekststykker hvor der dog i nogle tilfælde er blevet ændret et ord. Den enkelte deltager skal så vurdere om de to tekststykker er 
ens (hvilket tester deltagerens monitorering af den processerede information), og hvis hun vurderer at de er forskellige, skal hun forsøge at genkalde sig hvad ændringen indebærer (hvilket tester hvor god en repræsentation og lagring deltageren har opnået i processeringen af teksten i første præsentation). Ændringer der forekommer i de dele af teksten der er fremhævet, medfører reduceret ændringsblindhed (Sanford m.fl. 2006).

Dette gør metoden relevant for vores hypotese. Ledsætninger til baggrundede matrixsætninger, $\mathrm{fx}$ Nu har jeg det med at min dreng er ikke fyldt seks år, må antages at være forgrundede. Derfor forventer vi at ændringer i disse ledsætninger vil medføre reduceret ændringsblindhed i forhold til ændringer i ledsætninger til semifaktive matrixsætninger, hvor fordelingen af forgrund og baggrund ikke er afgjort af matrixsætningen i sig selv, fx Så må han overbevise dem om at vi ikke er sådan.

I de tilfælde hvor matrixsætningen ikke entydigt afgør hvilken del af helsætning der er forgrundet, forventer vi at ledstillingen i ledsætningen vil være et signal til at tolke den som henholdsvis forgrund eller baggrund. Derfor forventer vi for ledsætninger til semifaktive matrixsætninger at deklarativt ledstillingsmønster $(\mathrm{V}>\mathrm{Adv})$ medfører reduceret $æ$ ndringsblindhed i forhold til ledsætninger med neutralt ledsætningsmønster $(\mathrm{Adv}>\mathrm{V})$.

\section{Forsøg}

For at kunne teste effekten af matrixsætning og ledstilling har vi lavet et to gange to-design med variablene type af matrixsætning og ledstilling. En oversigt over de i alt fire betingelser for forsøget fremgår af Tabel 1.

\begin{tabular}{|l|l|l|}
\hline & $\begin{array}{l}\text { Semantisk sekundare } \\
\text { matrixsatninger (SS) }\end{array}$ & Semifaktive matrixsatninger (SF) \\
\hline V $>$ Adv & $\begin{array}{c}\text { A: Men jeg synes at det er ikke det samme } \\
\text { mere vel }\end{array}$ & $\begin{array}{r}\text { B: Hun har haft svært ved at acceptere at } \\
\text { jeg har ikke fået nogen uddannelse }\end{array}$ \\
\hline Adv $>$ V & $\begin{array}{l}\text { C: } \text { Men jeg synes at det ikke er det samme } \\
\text { mere vel }\end{array}$ & $\begin{array}{c}\text { D: Hun har haft svært ved at acceptere } \\
\text { at jeg ikke har fået nogen } \\
\text { uddannelse }\end{array}$ \\
\hline
\end{tabular}

Tabel 1. Oversigt over de fire betingelser i forsøget. 
59 studerende fra Københavns Universitet deltog i eksperimentet. Alle læste på humaniora, men ingen læste et sprogfag (herunder dansk) eller lingvistik. Alle havde dansk som modersmål, var normaltseende og typisk neurologisk udviklede uden læsevanskeligheder. Hver deltager læste 24 stimulussætninger (se Appendiks 1) og 36 fillersætninger. 12 af stimulussætningerne var konstruktioner med semantisk sekundære matrixsætninger og 12 med semifaktive matrixsætninger. 12 havde neutral ledstilling ( $\mathrm{Adv}>\mathrm{V}$ ), og 12 havde deklarativ ledstilling $(\mathrm{V}>\mathrm{Adv})$. Alle sætninger var baseret på faktisk forekommende ytringer i LANCHART-korpusset. Alle sætninger blev dog manipuleret for at holde en række variable konstant: Ud over ledfølgen i ledsætningen drejer det sig om at sætningsadverbialet i alle ledsætninger er $i k k e$, og subjektet er pronominelt. Stimulussætningerne blev præsenteret for deltagerne på computerskærme, og forsøget blev afviklet og programmeret ved hjælp af programmet PsychoPy (Peirce 2007).

Deltagerne læste hver sætning to gange. I alle sætninger, bortset fra fillersætningerne, var der ændret et ord anden gang deltageren læste sætningen. Dette ord var konsekvent placeret efter sætningsadverbialet i ledsætningen. Det nye ord matchede det oprindelige ord med hensyn til grammatisk status, semantik og i et vist omfang længde. Deltageren blev efterfølgende bedt om at vurdere om der var foretaget ændringer i sætningen, og i så fald hvad ændringen indebar (se Figur 2).

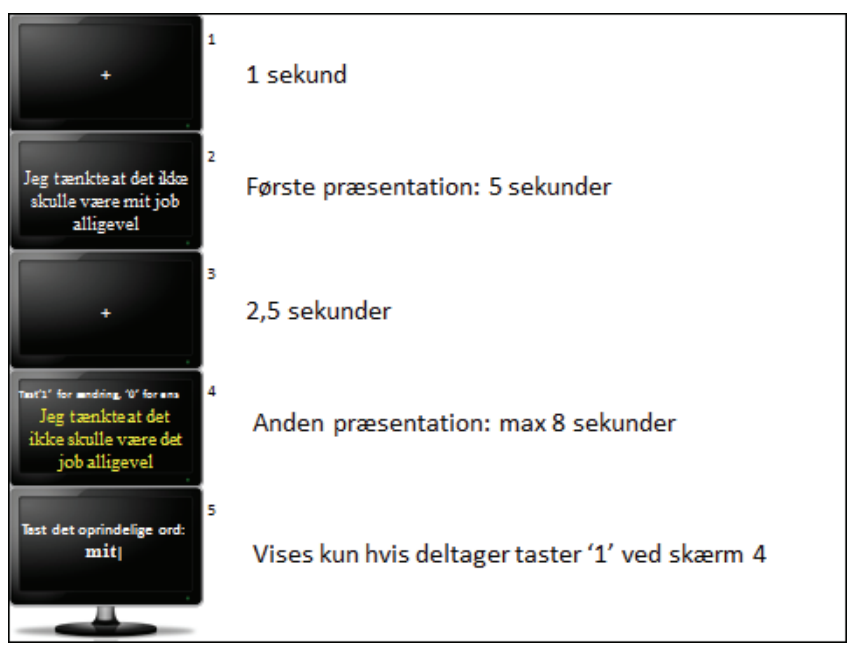

Figur 2: Forsøgsprocedure. Forsøgsdeltageren ser folgende 5 skerme for hver satning i forsøget. 
Materialet til forsøget blev fordelt på to lister for at sørge for at ingen deltagere så samme sætning med både $\mathrm{Adv}>\mathrm{V}-\mathrm{og} \mathrm{V}>\mathrm{Adv}-\mathrm{ledstilling} \mathrm{(dvs.} \mathrm{liste} 1$ indeholder sætning A i Tabel 1, og liste 2 indeholder sætning $\mathrm{C}$ og så fremdeles). For hver deltager registrerede vi to besvarelser, dels hvorvidt deltageren lagde mærke til en ændring i ledsætningen i anden præsentation, dels hvorvidt deltageren kunne genkalde sig hvad ændringen indebar, det vil sige kunne huske det oprindelige ord fra præsentation 1 (se skærm 5 i Figur 2).

\subsection{Databehandling}

Resultaterne blev analyseret ved hjælp af mixed models-analyser, som er en form for multipel logistisk regression der ud over faste faktorer (fixed effects) inddrager tilfældige faktorer (random effects) til opstilling af en matematisk model der beskriver hvorledes udfaldet af den afhængige variabel bedst muligt forudsiges (Baayen 2008; Tagliamonte \& Baayen 2012) ${ }^{1}$. Vi udarbejdede to modeller, en med deltagerens evne til at opdage en ændring (endringsregistrering) som afhængig variabel og en med deltagerens evne til at genkalde sig det oprindelige ord (ordgenkaldelse) som afhængig variabel. Vi analyserede effekten af dels de hypotesedrevne variable type af matrixsetning (semifaktive vs. semantisk sekundære) og ledstilling, dels en række potentielt intervenerende variable som vi gerne ville kontrollere for i den statistiske modellering: rakkefølge (den randomiserede rækkefølge som sætningerne blev vist i for hver deltager), liste samt forsøgsdeltagerens køn og "håndethed" (om deltageren var venstre- eller højrehåndet). Eftersom graden af ændringsblindhed givetvis afhænger af egenskaber både ved den konkrete sætning (dvs. ud over det som er relateret til type af matrixsætning og ledstilling) og ved deltageren (dvs. ud over det som måtte være relateret til køn og "håndethed"), har vi i modellen medtaget disse som tilfældige faktorer (jf. note 1) for at tage højde for tilfældig variation afstedkommet af dem.

1. Multipel logistisk regression indebærer at alle de inddragne faktorer vurderes samtidig, og at der derfor kontrolleres for alle de øvrige faktorer når effekten af en enkelt faktor evalueres mht. dens indflydelse på den afhængige variabel. En 'tilfældig' faktor adskiller sig fra en 'fast' faktor ved at de muligheder variablen kan variere imellem, må betragtes som stikprøver taget fra en større population. Mest åbenlyst gælder dette for den faktor der udgøres af sprogbrugeren: Sprogbrugerne er i udgangspunktet udvalgt tilfældigt fra en større population, og hvis man skulle replicere undersøgelsen, ville man være nødt til at vælge andre sprogbrugere. Samtidig forventer man at sprogbrugere har individuelle tilbøjeligheder som ikke forudsiges af de sociale og sproglige faktorer der er inddraget $i$ undersøgelsen, og en mixed model-analyse tager højde for sådanne idiosynkratiske tendenser mht. ændringsblindhed ved at tildele hver sprogbruger et individuelt basisgennemsnit (kaldet et random intercept) i forhold til den afhængige variabel (Christensen, Jensen \& Christensen 2015). 


\section{Resultater}

Den model der bedst beskriver variationen mht. deltagernes evne til at lægge mærke til en forandring i ledsætningerne (ændringsregistrering; eng. change detection), indeholder kun variablene matrixsætningstype(Pre-dicate Type) og ledstilling (WordOrder) samt disses interaktion med hinanden. Variablene rekkefolge, liste, kon og håndethed har med andre ord ikke en statistisk signifikant indflydelse på ændringsregistrering. Effekten af matrixsætningstype og ledstilling vises i Figur 3 nedenfor. Der er tale om såkaldt partielle effekter, dvs. variablenes effekt når der samtidig tages højde for at deltagerne ikke er lige gode til at lægge mærke til forandringer (den tilfældige variabel Deltager; eng. ParticipantID), og at sætningerne varierer mht. hvor let det er for forsøgsdeltagerne at lægge mærke til forandringer i dem (den tilfældige variabel stimulussætning, eng. ItemID). Den fulde model kan ses i Appendiks 2.

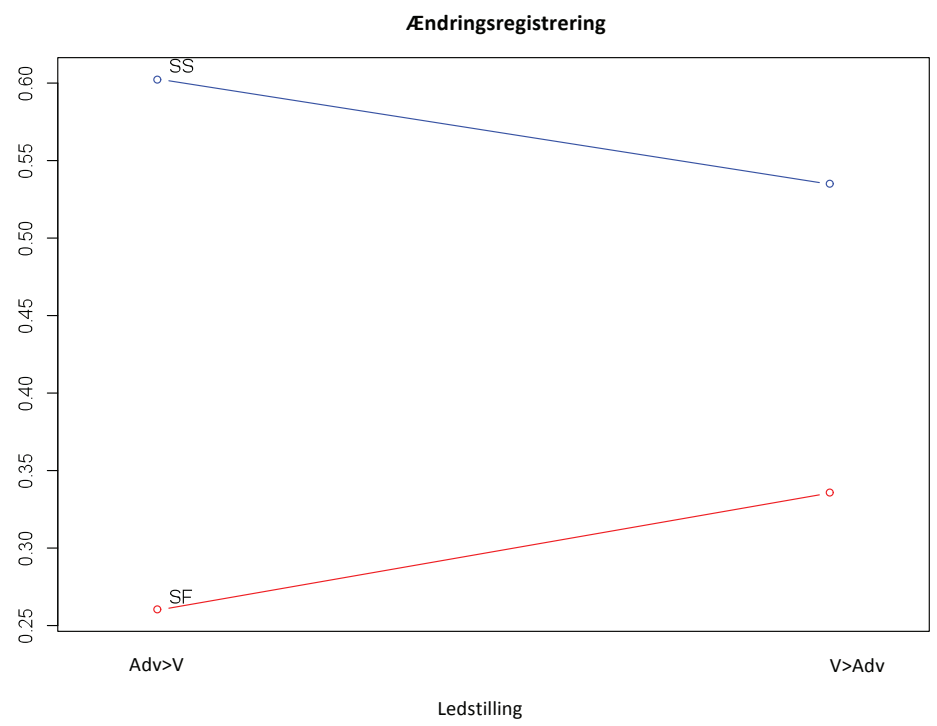

Figur 3: Partielle effekter, endringsregistrering. SS: semantisk sekundare matrixsetninger; SF: semifaktive matrixsatninger.

Det fremgår af Figur 3 at deltagerne har større sandsynlighed for at opdage en forandring i ledsætninger med en semantisk sekundær matrixsætning end i ledsætninger med en semifaktiv matrixsætning. Forskellen mellem de to typer matrixsætning er størst når ledsætningen har Adv $>$ V-ledstilling (neutral ledstilling), men den er statistisk signifikant også i forbindelse med V>Adv- 
ledstilling (deklarativ ledstilling): p-værdierne er henholdsvis 0,000190 og 0,0342. Resultatet bekræfter således hypotesen om at sprogbrugere er mere opmærksomme på ledsætninger hvis matrixsætning udgøres af epistemiske eller tekstuelle ordforbindelser, og som således kan siges at være forgrundede.

Også mht. effekten af ledsætningens ledstilling bekræftes vores hypotese: I ledsætninger med semifaktive matrixsætninger, dvs. ledsætninger som i udgangspunktet er åbne for såvel en forgrunds- som en baggrundslæsning, er sandsynligheden for at deltagerne opdager en forandring, signifikant større hvis ledsætningen har V $>$ Adv-ledstilling end hvis den har Adv $>$ V-ledstilling $(p=0,047540)$. Derimod er der som forventet ingen signifikant forskel mellem de to ledstillinger i semantisk sekundære matrixsætninger, dvs. ledsætninger som må betragtes som forgrundede uanset ledstillingen.

Den model der bedst beskriver variationen mht. deltagernes evne til at genkalde sig det ændrede ord (eng. original word retrieval), indeholder også kun variablene type af matrixsætning og ledstilling samt disses interaktion med hinanden. Den ligner således i vidt omfang modellen for ændringsregistrering bortset fra at andelene af korrekte svar er væsentligt lavere: I forbindelse med ændringsregistreringer den gennemsnitlige andel af korrekte svar $44 \%$ mens den kun er 30 for ordgenkaldelse; se Figur 4 nedenfor. Den fulde model kan ses i Appendiks 3.

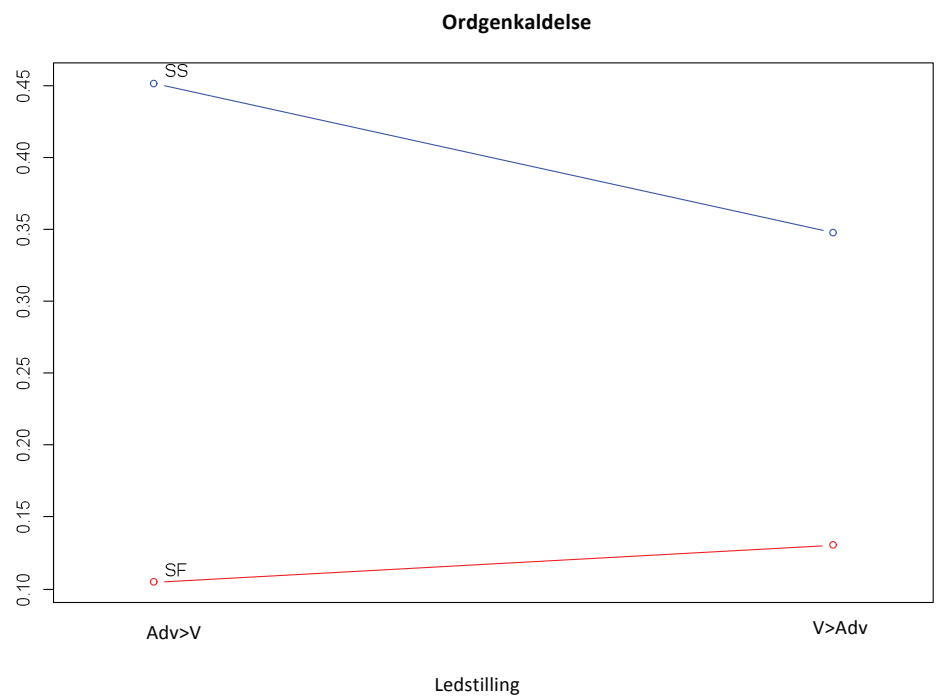

Figur 4: Partielle effekter, ordgenkaldelse. SS: semantisk sekundere matrixsetninger; SF: semifaktive matrixsatninger. 
Ligesom det var tilfældet i forbindelse med ændringsregistrering, er sandsynligheden for at genkalde sig det ændrede ord større i ledsætninger under semantisk sekundære matrixsætninger end under semifaktive matrixsætninger, og selvom forskellen er størst i forbindelse med Adv > V-ledstilling, er den signifikant uanset ledstillingen (p-værdierne er henholdsvis 0,000284 og 0,0177).

Tendenserne mht. ledstillingens effekt ligner også resultaterne i forbindelse med ændringsregistrering, men den positive effekt af $\mathrm{V}>$ Adv-ledstilling i ledsætninger i semifaktive matrixsætninger er mindre, og faktisk ikke statistisk signifikant ( $p=0,274602)$. Forsøget kan således ikke påvise at V $>A d v-l e d s t i l l i n g$ øger opmærksomheden for ledsætningens indhold når det drejer sig om ordgenkaldelse. Til gengæld er den uventede negative effekt af $\mathrm{V}>$ Adv-ledstilling vi også så i forbindelse med ændringsregistrering (men som der var svag og ikke signifikant), væsentligt mere udpræget, og statistisk signifikant ( $\mathrm{p}=0,020315)$.

\section{Diskussion}

Forsøget har vist at sprogbrugere er mere opmærksomme på indholdet i ledsætninger til semantisk sekundære matrixsætninger end på indholdet i ledsætninger til semifaktive matrixsætninger. Vi mener det vidner om at sprogbrugere i førstnævnte tilfælde tolker ledsætningen som den vigtigste del af helsætningen, og at det har processeringsmæssige konsekvenser. Sprogbrugeren er således mere opmærksom på ledsætningens indhold i de tilfælde hvor hun tolker ledsætningen som forgrundet, end i de tilfælde hvor hun ikke gør. På den måde afspejler processeringen informationsstrukturen. Processeringsresurserne organiseres så det informationsstrukturelt mest fremhævede bliver processeret mest grundigt.

Sturt m.fl. (2004) påpeger at øget opmærksomhed på en sætningsdel resulterer i grundigere processering og resulterer i mere fuldendte repræsentationer af den processerede tekst. Dvs. at reduceret ændringsblindhed, som defineret ovenfor, ikke bare kræver monitorering af den allerede processerede information når den genpræsenteres i anden præsentation af teksten. Reduceret ændringsblindhed kræver også præcis nok lagring af teksten i første præsentation til at kunne genkalde sig den oprindelige version af teksten når deltageren skal genkalde sig det ændrede ords oprindelige modsvar.

Vores resultater afslører en interessant nuancering af ledstillingens forskellige rolle i de to kognitive færdigheder (monitorering i anden præsentation og præcis lagring af første præsentation): Når det gælder monitorering af ledsætningen $i$ anden præsentation (det vil sige om man overhovedet opdager 
at der er en ændring i ledsætningen), spiller deklarativ ledstilling (V>Adv) en signifikant rolle som forgrundssignal i tilfælde hvor ledsætningen ikke i forvejen er forgrundet, men ingen væsentlig rolle i ledsætninger der i forvejen er forgrundede, helt som vi forventede.

Når det gælder genkaldelse af den nøjagtige repræsentation af første læsning af teksten, forholder det sig interessant nok anderledes. For ledsætninger der $i k k e$ er forgrundede som konsekvens af en bestemt type matrixsætning (dvs. i vores tilfælde ved semifaktive matrixsætninger), er effekten af ledstilling svagere når deltagerne skal genkalde sig det oprindelige ord, end når de blot skal vurdere om der er sket en ændring. Vi kan således her ikke påvise at deklarativ ledstilling i statistisk signifikant grad guider sprogbrugeren til en grundigere processering og dermed mere fuldendt lagring end neutral ledstilling $(\mathrm{Adv}>\mathrm{V})$. For ledsætninger der er konstruktionelt forgrundede (dvs. med semantisk sekundære matrixprædikater), forholder det sig overraskende nok sådan at deklarativ ledstilling medfører en mindre fuldendt repræsentation end neutral ledstilling dvs. ringere genkaldelse. Vi har på nuværende tidspunkt ingen forklaring på dette.

\section{Konklusion}

Vores eksperiment har vist at informationsstrukturelle forgrundssignaler som semantisk sekundære matrixsætninger og deklarativ ledstilling i ledsætninger under ikkebaggrundede matrixsætninger medfører reduceret ændringsblindhed, og vi har dermed bekræftet vores hypotese. Det betyder dels at ledsætningsprocessering er gradueret og processeringsgraden styres af opmærksomheden, dels at denne opmærksomhed afspejler informationsstrukturen i den processerede tekst. I et udvidet perspektiv bekræfter resultaterne at main clause-fænomener (jf. fx Green 1976 og Aelbrecht, Haegeman \& Nye 2012) har betydning for processeringen af ledsætninger. Forgrundingssignaler organiserer altså ikke bare diskursen, men fungerer samtidig som opmærksomhedsfangere i den sproglige processering. På baggrund af dette forsøg konkluderer vi at deklarativ ledstilling (V>Adv) i ledsætninger fungerer som opmærksomhedsfanger. Omvendt er det endnu ikke kortlagt hvilket forhold der er mellem deklarativ ledstilling og genkaldelse af allerede processeret information. Vores resultater antyder at forholdet er mere komplekst end hidtil antaget, og flere undersøgelser er påkrævet for at forklare det. 


\section{Appendiks 1: Oversigt over stimulussatninger}

Tabellen viser samtlige 24 sætninger fra liste 1 . Bemærk at tilsvarende sætninger med "modsat" ledstilling findes i liste 2. Ordet der ændres, er understreget, og det ord det bliver erstattet med i anden præsentation, er angivet i den yderste kolonne.

\begin{tabular}{|c|c|c|c|}
\hline & Prædikattype & Første præsentation & Ændringsord \\
\hline 1 & SF & $\begin{array}{l}\text { Til mødet forklarede han dem at han vidste ikke noget om } \\
\text { udnævnelsen inden han kiggede i telefonbogen }\end{array}$ & før \\
\hline 2 & SS & $\begin{array}{l}\text { Men det har noget at gøre med at du ikke tager sådan en } \\
\text { temmelig lille fyr med i kirken når der er begravelse vel }\end{array}$ & ind \\
\hline 3 & $\mathrm{SF}$ & $\begin{array}{l}\text { Efterhånden har hun accepteret at jeg har ikke nogen } \\
\text { forsikring til mine ældre dage hvis man kan sige det sådan }\end{array}$ & en \\
\hline 4 & SS & $\begin{array}{l}\text { Så tænkte jeg at det ikke skulle være det job alligevel hvis det } \\
\text { skulle være på den måde }\end{array}$ & mit \\
\hline 5 & $\mathrm{SF}$ & $\begin{array}{l}\text { Så må han overbevise dem om at vi ikke er sådan alle os fra } \\
\text { denne her bebyggelse vel }\end{array}$ & den \\
\hline 6 & SS & $\begin{array}{l}\text { Jeg kan godt mærke at jeg snakker ikke specielt meget mindre } \\
\text { jysk nu end jeg gjorde tidligere }\end{array}$ & særlig \\
\hline 7 & SF & $\begin{array}{l}\text { Og pludselig gik det op for hende at jeg ikke gik i skole og } \\
\text { sådan noget men rendte rundt og spiste is nede på Langelinie }\end{array}$ & så \\
\hline 8 & SS & $\begin{array}{l}\text { Det kan være at det er ikke kommunens eller min genbos eller } \\
\text { hvem ved jeg men min grund de har med at gøre }\end{array}$ & nabos \\
\hline 9 & SF & $\begin{array}{l}\text { Han har giort hende klart at han kan ikke klare alle børnene og } \\
\text { huset og ombygningen og det hele vel }\end{array}$ & begge \\
\hline 10 & SS & $\begin{array}{l}\text { Altså det korte af det lange er at der ikke var søgt kamerafolk til } \\
\text { TV og film alligevel og nu søgte de to }\end{array}$ & allerede \\
\hline 11 & SF & $\begin{array}{l}\text { Altså på sidste lønseddel opdagede han at han var ikke steget } \\
\text { de der omtrent halvtreds kroner i tillæg som han havde krav på }\end{array}$ & cirka \\
\hline 12 & SS & $\begin{array}{l}\text { Og så var det sådan noget med at vi ikke kunne få afsat gården } \\
\text { til den rigtige pris }\end{array}$ & solgt \\
\hline 13 & SF & $\begin{array}{l}\text { Det tog mange år for hende at indse at jeg ville ikke vende } \\
\text { tilbage til vores forhold nogensinde igen }\end{array}$ & komme \\
\hline 14 & SS & $\begin{array}{l}\text { Jeg kunne forestille mig at personen ikke var ret meget yngre } \\
\text { end den aldrende taler i lydprøve tre fordi lyden er meget } \\
\text { moden }\end{array}$ & ældre \\
\hline 15 & $\mathrm{SF}$ & $\begin{array}{l}\text { Her den anden dag hørte han at de kan ikke afskedige folk og } \\
\text { sådan noget derudefra på grund af nogle bestemte ting }\end{array}$ & derindefra \\
\hline 16 & SS & $\begin{array}{l}\text { Og så ved jeg at de ikke er så hårde imod børn men det } \\
\text { kommer an på hvad de har stjålet }\end{array}$ & overfor \\
\hline 17 & SF & $\begin{array}{l}\text { Og der kan hun jo forstå at vi ikke har ligget og grædt over at } \\
\text { der ikke var nogen familie til vores sølvbryllup vel }\end{array}$ & siddet \\
\hline 18 & SS & $\begin{array}{l}\text { Man skal tænke på at der er ikke varme med i det hun betaler i } \\
\text { husleje vel }\end{array}$ & han \\
\hline 19 & SF & $\begin{array}{l}\text { Og ret hurtigt viser det sig at hun ikke kan tåle hendes kat og } \\
\text { skal tage piller og jeg ved ikke hvad }\end{array}$ & $\sin$ \\
\hline 20 & SS & $\begin{array}{l}\text { Men ellers vil jeg mene at jeg snakker ikke sådan særlig } \\
\text { anderledes end min faster der også er københavner }\end{array}$ & vores \\
\hline
\end{tabular}




\begin{tabular}{|l|l|l|l|}
\hline 21 & SF & $\begin{array}{l}\text { Men hun har fundet ud af at hun ikke har helt så nemt ved at } \\
\text { læse og stave som Tommy }\end{array}$ & lige \\
\hline 22 & SS & $\begin{array}{l}\text { Nu har jeg det med at min dreng er ikke fyldt seks år i } \\
\text { indeværende skoleår vel så er han altså for lille }\end{array}$ & nuværende \\
\hline 23 & SF & $\begin{array}{l}\text { Min søster var jo kommet hjem og altså skulle han vænne sig til } \\
\text { at han ikke var den ældste længere og alt det her fis ikke }\end{array}$ & mere \\
\hline 24 & SS & $\begin{array}{l}\text { Nu vil jeg sige at jeg har ikke nogen intentioner på nogen vis } \\
\text { om at blande mig i det kunstneriske }\end{array}$ & måde \\
\hline
\end{tabular}

\section{Appendiks 2: Bedste model for andringsregistrering}

\begin{tabular}{|c|c|c|}
\hline & Estimate & $\mathrm{P}$ \\
\hline Intercept & 1.0463 & $0.000225 * * *$ \\
\hline PredicateType: semantically secondary & 1.4624 & $0.000190 * * *$ \\
\hline WordOrder: Verb>Adv & 0.3627 & $0.047540 *$ \\
\hline $\begin{array}{l}\text { PredicateType: semantically secondary } \\
\text { by WordOrder: Verb>Adv }\end{array}$ & -0.6398 & $0.011455 *$ \\
\hline \multicolumn{3}{|c|}{$\begin{array}{l}\text { Number of obs: 1272; ParticipantID: 53; ItemID: } 24 \\
\text { Random intercepts: } \\
\text { ParticipantID: Variance 0.1332; Std.Dev. } 0.3649 \\
\text { ItemID: Variance } 0.7151 \text {; Std.Dev. } 0.8457 \\
\text { The goodness of fit of the model is acceptable with a concordance statistic C of } 0.7780062 \text { and a } \\
\text { Somers' Dxy of } 0.5560124\end{array}$} \\
\hline
\end{tabular}

\section{Appendiks 3: Bedste model for ordgenkaldelse}

\begin{tabular}{|c|c|c|}
\hline & Estimate & $\mathrm{P}$ \\
\hline Intercept & -2.1451 & $8.28 \mathrm{e}-08 * * *$ \\
\hline PredicateType: semantically secondary & 1.9520 & $0.000284 * * *$ \\
\hline WordOrder: Verb $>$ Adv & 0.2485 & 0.274602 \\
\hline $\begin{array}{l}\text { PredicateType: semantically secondary } \\
\text { by WordOrder: Verb>Adv }\end{array}$ & -0.6843 & $0.020328 *$ \\
\hline \multicolumn{3}{|c|}{$\begin{array}{l}\text { Number of obs: 1272; ParticipantID: 53; ItemID: } 24 \\
\text { Random intercepts: } \\
\text { ParticipantID: Variance 0.3406; Std.Dev. } 0.5836 \\
\text { ItemID: Variance } 1.4209 \text {; Std.Dev. } 1.1920 \\
\text { The goodness of fit of the model is acceptable with a concordance statistic C of } 0.8478616 \text { and a } \\
\text { Somers' Dxy of } 0.6957233\end{array}$} \\
\hline
\end{tabular}




\section{Henvisninger}

Aelbrecht, L., L. Haegeman \& R. Nye (2012). Main Clause Phenomena. Amsterdam/ Philadelphia: John Benjamins Publishing Company.

Boye, K. \& P. Harder (2007). Complement-taking predicates: Usage and linguistic structure, Studies in Language 31(3), 569-606.

Baayen, R.H. (2008). Analyzing linguistic data. A practical introduction to statistics using $R$. Cambridge: Cambridge University Press.

Christensen, M.H. (2015a). Eksperimentelt design og dets konsekvenser for fortolkningen af stimuli: Substantiver i nøgenform og med udfyldt bestemmerplads, i S.E. Bentsen, et al. (red.) Ny forskning i grammatik 22, 77-91.

Christensen, M.H. (2015b). Endringsblindhed i sætningsprocessering i skriftlig dansk, MUDS 15, 45-57.

Christensen, T.K. (2007). Hyperparadigmer - en undersogelse af paradigmatiske samspil $i$ danske modussystemer. Ph.d.-afhandling, Roskilde Universitetscenter.

Christensen, T.K. \& T.J. Jensen (2014). Sætningsadverbialer i ledsætninger som forgrundssignal, i M. Birkelund, et al. (red.) Ny Forskning i Grammatik 21, 37-53.

Christensen, T.K., T.J.Jensen \& M.H. Christensen (2015). Adverbielle ledsætningers ledstilling i dansk talesprog, MUDS 15, 97-115.

Ferreira, F., K.G. Bailey \& V. Ferraro (2002). Good-enough representations in language comprehension, Current directions in psychological science 11(1), 11-15.

Green, G.M. (1976). Main clause phenomena in subordinate clauses, Language 52(2), 382-397.

Hansen, E. \& L. Heltoft (2011). Grammatik over det Danske Sprog. København \& Odense: Det Danske Sprog- og Litteraturselskab \& Syddansk Universitetsforlag.

Hooper, J.B. \& S.A. Thompson (1973). On the applicability of root transformations, Linguistic Inquiry 4(4), 465-497.

Jensen, T.J. (2011). Ordstilling i ledsætninger i moderne dansk talesprog, i P. DurstAndersen \& H.H. Müller (red.) Ny Forskning i Grammatik 18, 123-150.

Jensen, T.J. \& T.K. Christensen (2013). Promoting the demoted: The distribution and semantics of "main clause word order" in spoken Danish complement clauses, Lingua 137, 38-58.

Karttunen, L. (1971). Implicative verbs, Language 27(2), 340-358.

Peirce, J. (2007). PsychoPy - Psychophysics software in Python., 7 Neurosci Methods 162(1-2), 8-13.

Sanford, A.J., et al. (2006). Shallow processing and attention capture in written and spoken discourse, Discourse Processes 42(2), 109-130. 
Simons, M. (2007). Observations on embedding verbs, evidentiality, and presupposition, Lingua 117, 1034-1056.

Sturt, P., et al. (2004). Linguistic focus and good-enough representations: An application of the change-detection paradigm, Psychonomic Bulletin \& Review 11(5), 882-888.

Tagliamonte, S.A. \& R.H. Baayen (2012). Models, forests, and trees of York English: Was/were variation as a case study for statistical practice, Language Variation and Change 24(2), 135-178.

Thompson, S.A. (2002). 'Object Complements' and Conversation: towards a realistic account, Studies in Language 26(1), 125-164.

Thompson, S.A. \& A. Mulac (1991a). The discourse conditions for the use of the complementizer that in conversational English, fournal of Pragmatics 15(3), 237-251.

Thompson, S.A. \& A. Mulac (1991b). A quantitative perspective on the grammaticalization of epistemic parentheticals in English, i E.C. Traugott \& B. Heine (red.) Approaches to grammaticalization, Amsterdam: John Benjamins, 313-329.

Urmson, J.O. (1963). Parenthetical verbs, i C.E. Caton (red.) Philosophy and ordinary language, Urbana: University of Illinois Press. 